\title{
Development of a Novel Commutation Method which Drastically Suppresses Commutation Failure of a Matrix Converter
}

\author{
Koji Kato Student Member (Nagaoka University of Technology) \\ Jun-ichi Itoh Member (Nagaoka University of Technology)
}

Keywords: commutation, matrix converter, commutation error compensation

This paper proposes the safest novel commutation method for a matrix converter. There are two conventional commutation methods which depend on the polarity of the input line voltage (it is called "voltage commutation") and depend on the polarity of the output current (it is called "current commutation"). However, problem of the voltage commutation is that commutation failure occurs around zero of the input line voltage. It is difficult to detect its polarity due to depending on offset and delay of the sensor. Similarly, the current commutation failure occurs around zero of the load current. A cause of these detection error are a detection delay and an offset of a sensor.

Figure 1 shows a principle of the proposed commutation method. The proposed commutation method combines the voltage commutation and the current commutation as follows.

- Zero crossing point in the load current: voltage commutatiom

- Others: current commutation

Therefore, the proposed commutation method can decrease the commutation failure without high accuracy sensor. In addition, a voltage error compensation based on the proposed commutation method is proposed in this paper. The proposed method can simply compensate for the commutation error of the output voltage and the input current at the same time.

The effects of the proposed method are confirmed by experimental results with a $750 \mathrm{~W}$ induction motor and a R-L load.

Figure 2 shows the experimental results of each commutation methods. The commutation failure of voltage commutation is occurring when cross point of the input voltage magnitude. Similarly, the commutation failure of the current commutation is occurring when around zero crossing point in the load current. On the other

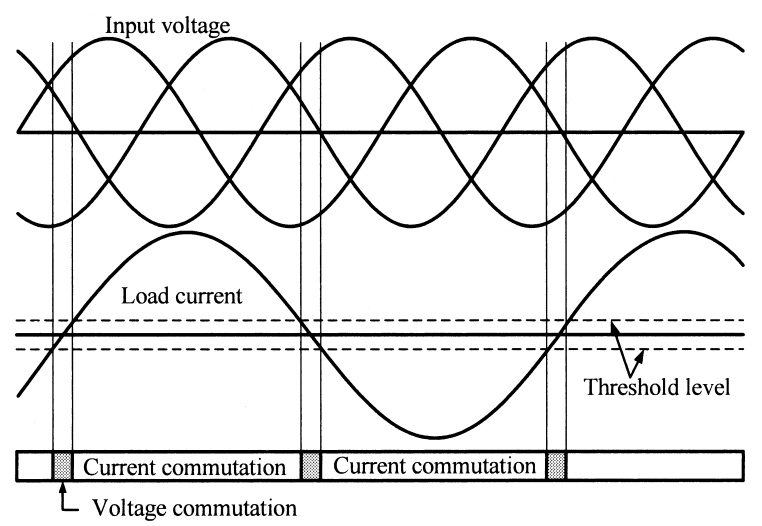

Fig. 1. Proposed commutation method hand, the commutation failure of the proposed commutation is not occuring. Therefore, those results confirm that the proposed commutation can decrease commutation failure.

Figure 3 shows the comparison of the total harmonics distortion (T.H.D.) of the input current and output current. The T.H.D. of the input current and the output current are 2.6 point and 0.9 point lower than that of the condition without the compensation at $100 \%$ output power.

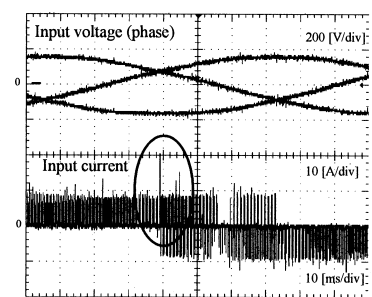

(a) Voltage commutation.

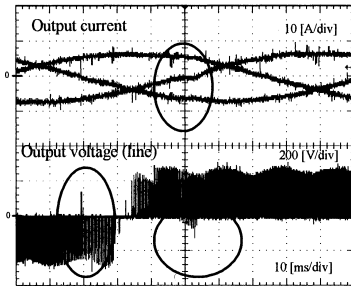

(c) Current commutation

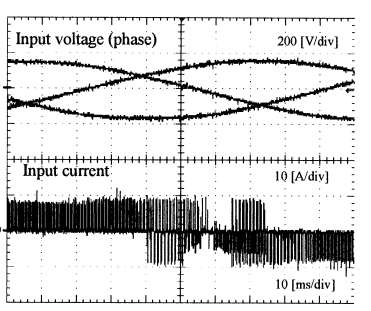

(b) Proposed commutation.
Fig. 2. Experimental result of voltage commutation, current commutation and proposed commutation (R-L load)

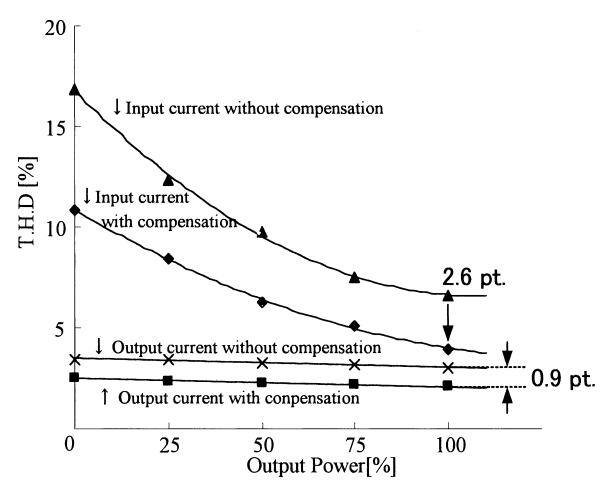

Fig. 3. Experimental result of motor load 


\title{
マトリックスコンバータの転流失敗を激減する 新しい転流方式の開発
}

\author{
学生員 加藤 康司* 正 員 伊東 淳一* \\ Development of a Novel Commutation Method which Drastically Suppresses \\ Commutation Failure of a Matrix Converter \\ Koji Kato*, Student Member, Jun-ichi Itoh*, Member
}

\begin{abstract}
This paper proposes the safest novel commutation method for a matrix converter. There are two conventional commutation methods which depend on the polarity of the input line voltage (it is called "voltage commutation") and depend on the polarity of the output current (it is called "current commutation"). However, problem of the voltage commutation is that commutation failure occurs around zero of the input line voltage. It is difficult to detect its polarity due to depending on offset and delay of the sensor. Similarly, the current commutation failure occurs around zero of the load current. A cause of these detection errors are a detection delay and an offset of a sensor. The proposed commutation method combines the input voltage commutation and the load current commutation. Therefore, the proposed commutation method can decrease the commutation failure without high accuracy sensor. In addition, a voltage error compensation based on the proposed commutation method is proposed in this paper. The proposed method can simply compensate for the commutation error of the output voltage and the input current at the same time.

The effects of the proposed method are confirmed by experimental results with a $750 \mathrm{~W}$ induction motor and a R-L load. Those results confirm that the proposed commutation can decrease commutation failure. Moreover, the total harmonics distortion of the input current and the output current are 2.6 point and 0.9 point lower than that of the condition without the compensation at $100 \%$ output power.
\end{abstract}

キーワード：転流，マトリックスコンバータ，転流誤差補償

Keywords: commutation, matrix converter, commutation error compensation

\section{1. はじめに}

近年, 逆耐圧をもつ IGBT が開発されており ${ }^{(1)}$, 交流電源 から任意の交流電圧, 周波数を直接出力できるマトリック スコンバータが注目され, 盛んに研究されている(2) (6)。マ トリックスコンバータは従来のダイオード整流器を使った システムに比べ，入力電流を正弦波にできるため入力電流 高調波を低減でき，回生動作が可能であるため，省エネ，高 効率の面で優れている。また, PWM 整流器とインバータ システムに対しては, 直流バスが存在しないため大型の電 解コンデンサが不要であり小型化, 長寿命化の面でも優れ ている。

マトリックスコンバータの主回路は両方向の電圧と電流 を制御できる双方向スイッチ9個と入力フィルタから構成さ

\footnotetext{
*長岡技術科学大学

于 940-2188 長岡市上富岡町 1603-1

Nagaoka University of Technology

1603-1, Kamitomioka, Nagaoka 940-2188
}

れる。このような独自の回路構成であるマトリックスコン バータの問題点として転流がある。マトリックスコンバー タでは, 電源短絡の防止に加え, 誘導性負荷の場合, スイッ チング素子に印加するサージ電圧を防止するため負荷開放 しないようにスイッチングを行う必要がある。これを回避 し，電流を転流する方式について，さまざまな方法 ${ }^{(7) \sim(15)}$ が 提案されているが, 基本的には入力電圧の大小関係を監視 して転流する方法（電圧転流方式）と, 負荷電流極性を監 視して転流する方法（電流転流方式）の 2 つに大別される。 これらは, いずれも電源電圧の大小関係，また負荷電流の 極性ゼロクロス付近で，センサの誤差や検出遅れにより転 流失敗が発生しやすい。この転流失敗によりサージ電圧や サージ電流が発生し, 最悪の場合, 素子を破壊する恐れが ある。電源電圧の大小関係や, 電流極性を正確に検出する ために, センサの精度を高くすると検出回路が複雑になり, コストアップの原因となる。転流失敗が多発すると, サー ジ電流とサージ電圧を吸収するスナバ容量が大きくなり, またスイッチング素子の寿命にも悪影響を及ぼす。 
転流におけるスイッチの切り替えは, 転流時間を設け, 電 源短絡と負荷開放をしないように 4 ステップに分けて確実 に電流を転流する方式が一般的である。これを簡単化する ため，スイッチング素子のターンオンとターンオフ時間の 違いに着目した 2 ステップ転流 ${ }^{(16)}$ がある。2 ステップ転流 は，転流完了までの時間が短く，転流パターンが簡単であ るなどの利点がある。しかし，デバイスの特性に依存して いるので, 温度やばらつきによってはスイッチングの際に, 各出力相のスイッチ群は同時オン, または同時オフが発生 し，電源短絡，負荷開放が起こる危険性がある。また，電 圧転流方式において, 中間相を経由せず, 最大相と最小相 の間で直接スイッチングさせる方法がある(17)。しかし，こ の方法では, 1 回の電圧変化が大きいため, スイッチング 損失が増加する。

一方, 転流を行うことで, インバータのデッドタイム誤 差と同様に, 出力電圧に誤差が発生する。インバータの場 合, この電圧誤差はシステムの外乱となり, 特にモータド ライブシステムの制御性能の劣化をもたらすため, 高い制 御性能を発揮するにはデッドタイムにより発生する䛊差電 圧の補償が重要である。マトリックスコンバータの場合で も同様に，高い制御性能を発揮するには電圧誤差を補正し なくてはならない。従来では出力電圧に生じる誤差を出力 電圧指令に加算して補正する方式が一般的である。この場 合, 出力電圧はよいが, 転流に伴う誤差が入力電流波形に は残存する。

本論文では, 入力電圧の大小関係と負荷電流極性の両方 を用いて 4 ステップの電圧転流方式と電流転流方式を組み 合わせる方式を提案する。この方式は，センサの検出精度 を高めることなく，転流失敗の発生する確率を低減できる。 次に，各相のパルスのオン時間に着目することにより，転 流方式によって発生するパルス幅の誤差の関係を明らかに し，提案する転流方式においても簡単に転流誤差を補償す る方法を提案する。この方法は簡単である上，入力電流波 形と出力電流波形の両方に生じる転流にともなう誤差を補 正できる。最後に, 実験により, 従来の転流方式と提案す る転流方式を比較し, 電圧転流方式と電流転流方式の両方 の長所を有することを確認したので報告する。

\section{2. 従来の転流方式とその問題点}

図 1 に示す双方向スイッチ 2 個の回路において, 電源 $v_{1}$ から $v_{2}$ へ転流することを考える。マトリックスコンバータ は, スイッチング時の電源短絡を防止し, 誘導性負荷の場 合, 負荷リアクトルに流れる電流の連続性を確保するため, 負荷開放しないようにスイッチングしなくてはならない。 つまり, 各出力相のスイッチ群は同時オンも同時オフも許 容されない。スイッチング時の転流は, 基本的に入力電圧 の大小関係を監視して転流する電圧転流方式と, 負荷電流 の極性を監視して転流する電流転流方式がある。以下に従 来の 4 ステップの電圧転流方式と電流転流方式の転流シー ケンスと，その問題点について説明する。 $\langle\mathbf{2} \cdot \mathbf{1}\rangle$ 電圧転流方式図 $2(\mathrm{a}) に v_{1}>v_{2}$, 図 2(b)に $v_{1}<v_{2}$ の場合の, 電圧転流方式における $\mathrm{S}_{1}$ と $\mathrm{S}_{2}$ のスイッ チングを示す。電圧転流方式は入力電圧の大小関係を監視 して転流を行うので，図2(a)のように， $v_{1}>v_{2}$ の場合，ス イッチを $\mathrm{S}_{1}$ から $\mathrm{S}_{2}$ へ切り替えるとすると, 転流シーケン スは以下のようになる。

初期状態 $\mathrm{ON}: \mathrm{S}_{1 \mathrm{a}}, \mathrm{S}_{1 \mathrm{~b}} \quad \mathrm{OFF}: \mathrm{S}_{2 \mathrm{a}}, \mathrm{S}_{2 \mathrm{~b}}$
(1) $\mathrm{S}_{2 \mathrm{a}} \mathrm{ON}$
(2) $\mathrm{S}_{1 \mathrm{a}} \quad \mathrm{OFF}$
(3) $\mathrm{S}_{2 \mathrm{~b}} \mathrm{ON}$
(4) $\mathrm{S}_{1 \mathrm{~b}} \quad \mathrm{OFF}$

上記のように，電源短絡を防止するため転流時間 $T_{d}$ を 設け(1)から(4)へスイッチを切り替え，転流を行う。

図 2(a)において， $v_{1} ， v_{2}$ の值が接近すると，センサの精 度不足よる検出誤差や遅れなどにより, 電圧の大小関係の 判別が困難になり, 検出值と実際の值に誤りが生じる。検 出值が $v_{1}>v_{2}$ であるが, 実際は $v_{1}<v_{2}$ であるとき, $\mathrm{S}_{1 \mathrm{~b}}$ と $\mathrm{S}_{2 \mathrm{a}}$ が同時にオンする(2)から(4)の期間で， $v_{2}$ から $v_{1}$ へ短 絡電流が流れ，転流失敗する。

$\langle\mathbf{2} \cdot \mathbf{2}\rangle$ 電流転流方式図 3(a) に $i_{\text {load }}>0$, 図 3(b) に

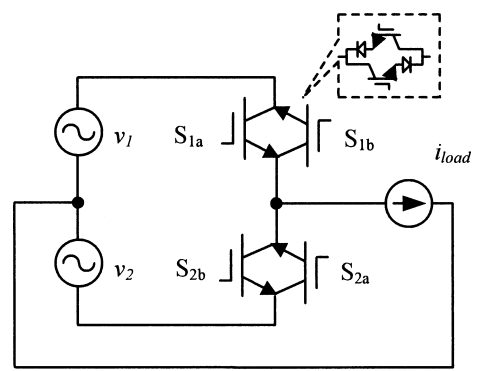

図 1 転流モデル

Fig. 1. Commutation model.

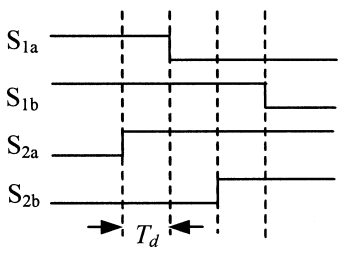

(a) Voltage commutation. $\left(v_{1}>v_{2}\right)$

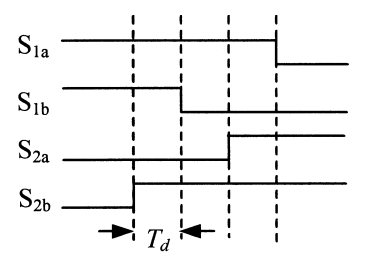

(b) Voltage commutation. $\left(v_{1}<v_{2}\right)$
図 2 電圧転流パターン

Fig. 2. Voltage commutation pattern of Fig. 1.

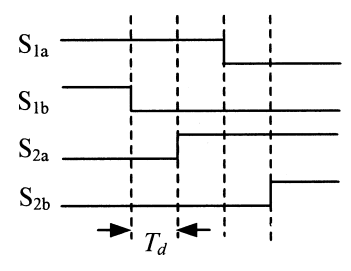

(a) Current commutation. $\left(i_{\text {load }}>0\right)$

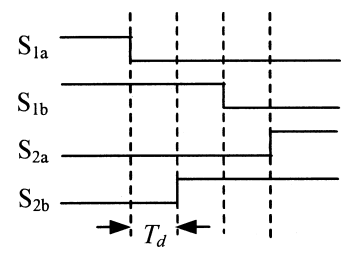

(b) Current commutation. ( $\left.i_{\text {load }}<0\right)$
図 3 電流転流パターン

Fig. 3. Current commutation pattern of Fig. 1. 
$i_{\text {load }}<0$ の場合の, 電流転流方式における $\mathrm{S}_{1}$ と $\mathrm{S}_{2}$ のスイッ チングを示す。電流転流方式は負荷電流の極性を監視して 転流を行うので, 図 3(a)のように, $i_{\text {load }}>0$ の場合, スイッ 于を $\mathrm{S}_{1}$ から $\mathrm{S}_{2}$ へ切り替えるとすると，転流シーケンスは 以下のようになる。

初期状態 $O N: S_{1 a}, S_{1 b} \quad$ OFF : $S_{2 a}, S_{2 b}$
(1) $\mathrm{S}_{1 \mathrm{~b}} \mathrm{ON}$
(2) $\mathrm{S}_{2 \mathrm{a}}$ OFF
(3) $\mathrm{S}_{1 \mathrm{a}} \mathrm{ON}$
(4) $\mathrm{S}_{2 \mathrm{~b}}$ OFF

上記のように，負荷開放を防止するため転流時間 $T_{d}$ を 設け(1)から(4)へスイッチを切り替え，転流を行う。

図3(a)において, 負荷電流ゼロクロス付近で, 負荷電流 が小さくなると，センサの精度不足による検出誤差や遅れ などにより, 電流極性の判別が困難になり, 検出値と実際の 值に誤りが生じる。検出した電流の極性が $i_{\text {load }}>0$ である が, 実際は $i_{\text {load }}<0$ であるとき, (2) (4)の期間で $\mathrm{S}_{1 \mathrm{~b}}$ と $\mathrm{S}_{2 \mathrm{~b}}$ が同時にオフになる。この間, $i_{\text {load }}<0$ の電流経路が存在 しなくなり, 電流の連続性を確保できなくなる。誘導性負 荷の場合, 出力電圧に過大なサージ電圧を発生させ, 転流 失敗する。また, 電流転流方式は, 負荷電流の極性によっ て，転流パターンを決定しているため，電流極性信号には 逆ヒステリシス特性を持たせなければならない。

\section{3. 提案する転流方法}

前述のように，電圧転流方式は電源電圧切り替わり付近 において，電流転流方式は負荷電流の極性切り替わり付近 に扔いて，センサの検出誤差や遅れにより転流失敗が発生 しやすい。そこで，提案する転流方式は下記のごとく，転 流方式を切り替える。

-入力電圧の大小関係切り替り付近... 電流転流方式

・負荷電流のゼロクロス付近…電圧転流方式

図 4 は提案する転流方式の原理図である。入力電圧の大 小切り替わり付近で電流転流を行うことにより, 電源電圧 の大小関係によらず転流を行い，また出力電流のゼロクロ ス付近で電圧転流を行うことで, 負荷電流の極性によらず

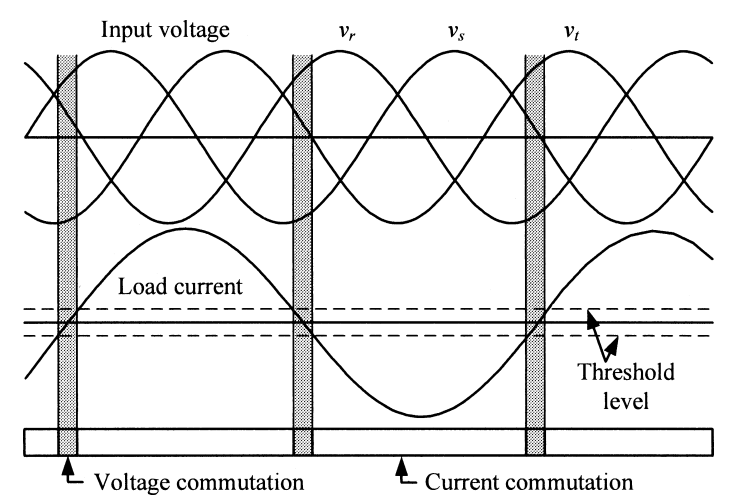

図 4 提案する転流方式

Fig. 4. Proposed commutation method.
転流を行う。そのため, 正確に電源電圧の大小関係, 負荷 電流の極性を検出しなくても, 転流失敗を低減できる。

電流転流方式は, 負荷電流により転流パターンを決定す るので, 電流が出力電圧に対しフィードバック的に作用す る。この結果，電流転流では負荷電流の極性検出を誤った 場合, 負荷電流がゼロ付近に停滞することがある。特に, 極 低速で電流振幅が小さいときなどに失敗が生じやすい。一 方, 電圧転流方式は, 入力電圧によって転流パターンを決 定するので，比較的安定に動作できる。そのため, 電源電 圧の大小関倸切り替わり付近と負荷電流のゼロクロス付近 が重なる場合は，電圧転流方式を優先する。

な㧍, 出力電流が小さく, 電源電圧の大小切り替わりが 同時に起こることが予想されるが，このような場合，その 1 回に扔いては, 本方式に扔いても転流失敗の可能性があ る。しかし, 転流失敗の可能性が増加する回数を考えると, 従来の転流方式では 1 周期中に 6 回であるのに対し, 提案 する方式では, 入力電圧の周期と出力電流の周期の最小公 倍数となる。その結果, トータルの転流失敗の回数は激減 する。

図 5 に出力 1 相分の提案する転流方式の構成を示す。ソ

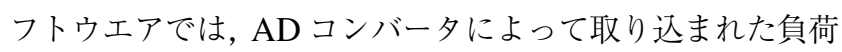
電流の大きさと, 転流切り替えレベル (Threshold level) を比 較することで転流方式選択信号 (Commutation command) を決定し, 負荷電流の極性により電流極性信号 (Current direction signal）を作成する。FPGA では，検出した入力電 圧の大小関係信号（Voltage commutation signal）を用いて, ゲートパルスに電圧転流パターンを付加する。また, ソフ トゥエアで判別した電流極性信号を用いて, ゲートパルス に電流転流パターンを付加する。転流方式選択信号により, 電圧転流パターンまたは電流転流パターンのいずれかを選 択する。転流方式の切り替えレベルは, 負荷電流極性検出 の精度に依存する。今回は, AD コンバータによって取り 込まれた負荷電流の極性を, ソフトウエアにて判別してい るため, ゼロ付近の切り替え精度は高くない。そのため, 切 り替えレベルを定格電流の $20 \%$ としている。な抢，ゼ口付

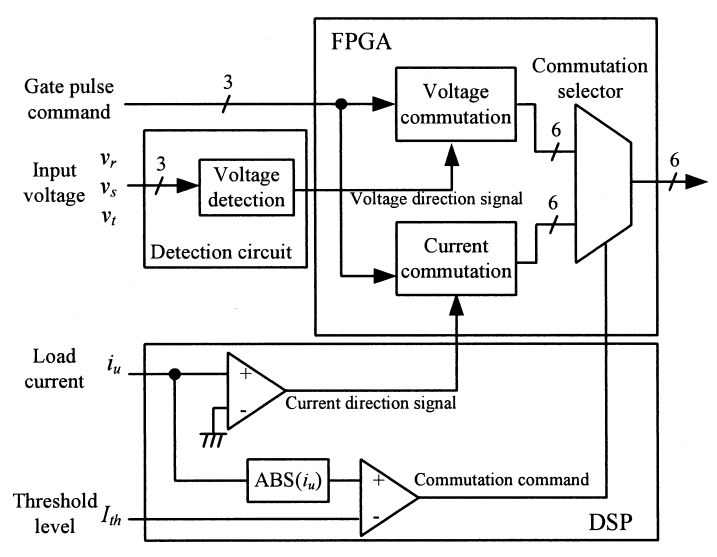

図 5 提案する転流方式の構成

Fig. 5. Configuration of proposed commutation method. 
近以外では電流は停滞しないため，切り替えに際してのヒ ステリシスは必要ない。

\section{4. 転流により発生する誤差}

インバータの場合，高い制御性能を発揮するにはデッド タイムにより発生する誤差電圧の補償が重要である。マト リックスコンバータの場合でも同様に，高い制御性能を発 揮するには電圧誤差を補正しなくてはならない。

図 6(a)の $v_{\text {max }}, v_{\text {mid }}, v_{\text {min }}$ はそれぞれ任意の状態におけ る入力電圧の最大相, 中間相, 最小相を示し, 各相のスイッ チオン時間指令を $T_{\text {max }}{ }^{*} ， T_{\text {mid }}{ }^{*} ， T_{\text {min }}{ }^{*}$ とする。いま，

最大電圧一中間電圧一最小電圧一中間電圧一最大電圧

のようにスイッチングすると仮定すれば， 1 キャリア周期 中に 4 回転流が発生する。

従来では, 転流に伴う誤差補正法は発生する出力誤差電 圧を出力電圧指令に対してフィードフォワードする方式が 一般的である。本方式では，電流転流と電圧転流を組み合 わせて使用することから，補償方式が複雑化することが予 想される。そこで，本論文では，各パルスのオン時間に着 目し，転流により生じる誤差パルスを補正する方法を提案 する。この結果，転流誤差補償はきわめて簡単になるうえ， 入力電流と出力電圧波形の両方を同時に補償できる。以下 に，各相のオン時間に着目して電圧転流と電流転流におけ る誤差パルス幅を検討する。

〈4・1〉 電圧転流方式により発生する電圧誤差＼cjkstart図 6(b) に電圧転流方式の PWM パルス指令と，それに電圧転流を 付加した PWM パルス, 出力電圧誤差を示す。出力電圧に おいて, 点線が指令出力電圧であり, 実線が実際の出力電圧 である。PWM パルス指令に転流動作が付加されると, 各ス イッチがオンする時間は実際にオンする時間を $T_{\text {max }}, T_{\text {mid }}$, $T_{\text {min }}$ とし, 負荷電流を $i_{\text {load }}, 1$ ステップの転流時間を $T_{d}$ と すれば(3) 式となる。

$$
\left\{\begin{array} { l } 
{ T _ { \operatorname { m a x } } = T _ { \operatorname { m a x } } { } ^ { * } - T _ { d } } \\
{ T _ { \text { mid } } = T _ { \text { mid } } { } ^ { * } } \\
{ T _ { \operatorname { m i n } } = T _ { \operatorname { m i n } } { } ^ { * } + T _ { d } } \\
{ \quad ( i _ { \text { load } } > 0 ) }
\end{array} \quad \left\{\begin{array}{l}
T_{\max }=T_{\max }{ }^{*}+T_{d} \\
T_{\operatorname{mid}}=T_{\operatorname{mid}}{ }^{*} \\
T_{\min }=T_{\min }{ }^{*}-T_{d} \\
\quad\left(i_{\text {load }}<0\right)
\end{array}\right.\right.
$$

(3) 式から, 電圧転流方式では $T_{\text {max }}$ と $T_{\text {min }}$ が転流時間 $T_{d}$ だけ増減する。負荷電流極性によって $T_{\text {max }}$ と $T_{\text {min }}$ を $T_{d}$ だ け増加または減少させ, 誤差電圧を発生させる。この電圧 転流を付加したときに発生する出力電圧 $v_{V \text { comm }}$ は (4) 式の ように指令電圧 $v^{*}$ と誤差電圧で表せる。ただし， $f_{s}$ はキャ リア周波数, $y=\operatorname{sign}(x)$ は符号関数で, $x>0$ のとき $y=1$, $x<0$ のとき $y=-1$ である。

$$
v_{V \text { comm }}=v^{*}-\left(v_{\max }-v_{\min }\right) T_{d} f_{s} \operatorname{sign}\left(i_{\text {load }}\right) .
$$

電圧転流方式により生じた転流誤差を補償するためには， (5) 式のように, 負荷電流極性に応じて $T_{\text {max }}{ }^{*}$ と $T_{\text {min }}{ }^{*}$ を $T_{d}$ だけ補償し， $T_{\text {max }}{ }^{* *}$ と $T_{\text {min }}{ }^{* *}$ を求めればよい。

$$
\left\{\begin{array}{l}
T_{\max }{ }^{* *}=T_{\max }{ }^{*}+T_{d} \operatorname{sign}\left(i_{\text {load }}\right) \\
T_{\min }{ }^{* *}=T_{\text {min }}{ }^{*}-T_{d} \operatorname{sign}\left(i_{\text {load }}\right)
\end{array}\right.
$$

〈4・2〉電流転流方式により発生する電圧誤差 図 6(c) に電流転流方式の PWM パルス指令と, それに電流転流を 付加した PWM パルス, 出力電圧誤差を示す。電流転流方 式も電圧転流方式と同様に, PWM パルス指令に転流動作 が付加されると, 各スイッチがオンする時間は以下のよう になる。

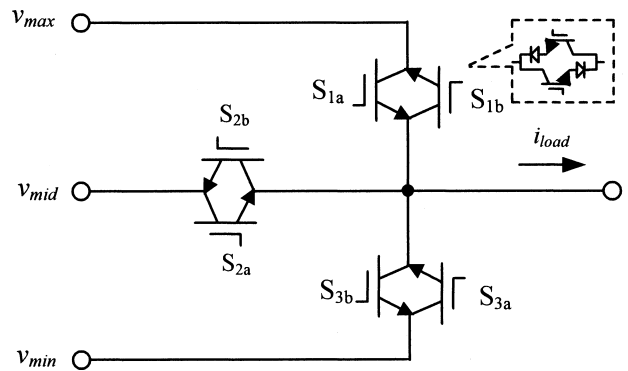

(a) Configuration of matrix converter.

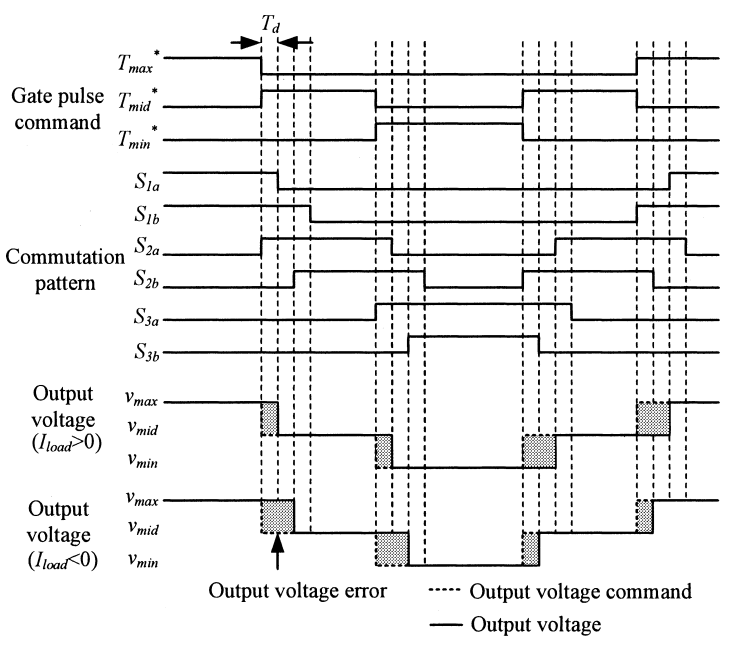

(b) Voltage error in case of voltage commutation.

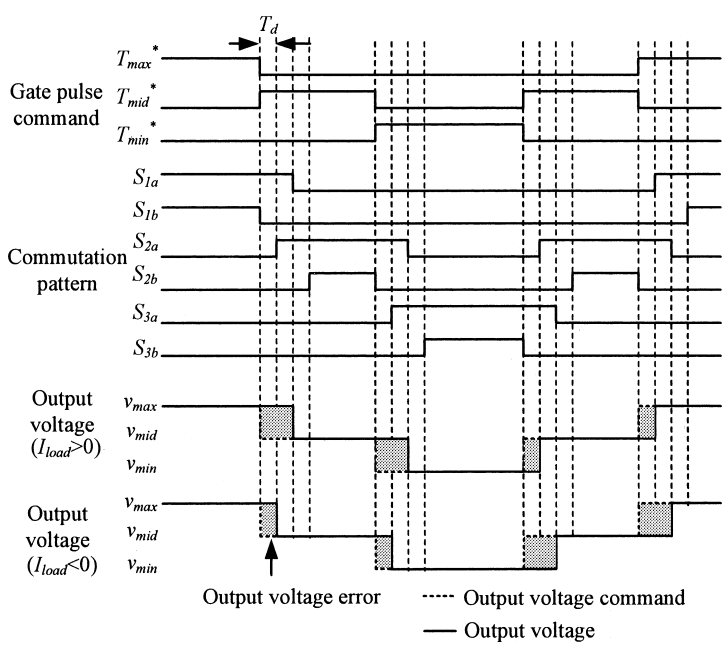

(c) Voltage error in case of current commutation.

図 6 転流による電圧誤差

Fig. 6. Behavior of voltage error by commutation. 


$$
\left\{\begin{array} { l } 
{ T _ { \operatorname { m a x } } = T _ { \text { max } } { } ^ { * } + T _ { d } } \\
{ T _ { \text { mid } } = T _ { \text { mid } } { } ^ { * } } \\
{ T _ { \operatorname { m i n } } = T _ { \operatorname { m i n } } { } ^ { * } - T _ { d } } \\
{ \quad ( i _ { \text { load } } > 0 ) }
\end{array} \quad \left\{\begin{array}{l}
T_{\max }=T_{\max }{ }^{*}-T_{d} \\
T_{\text {mid }}=T_{\text {mid }}{ }^{*} \\
T_{\min }=T_{\min }{ }^{*}+T_{d} \\
\quad\left(i_{\text {load }}<0\right)
\end{array}\right.\right.
$$

電流転流方式においても，(6) 式のように負荷電流極性に よって $T_{\text {max }}$ と $T_{\text {min }}$ に $T_{d}$ が誤差として付加する。(7) 式に 示す電流転流方式によって出力する電圧 $v_{\text {Icomm }}$ も, 電圧転 流方式と同様に，指令電圧 $v^{*}$ と誤差電圧で表せる。

$$
v_{\text {Icomm }}=v^{*}-\left(v_{\max }-v_{\min }\right) T_{d} f_{s} \operatorname{sign}\left(i_{\text {load }}\right)
$$

電流転流方式も (8) 式のように負荷電流極性に応じて $T_{\text {max }}{ }^{*}$ と $T_{\text {min }}{ }^{*}$ を $T_{d}$ だけ補償し, $T_{\text {max }}{ }^{* *}$ と $T_{\text {min }}{ }^{* *}$ を求め ればよい。

$$
\left\{\begin{array}{l}
T_{\max }{ }^{* *}=T_{\max }{ }^{*}-T_{d} \operatorname{sign}\left(i_{\text {load }}\right) \\
T_{\min }{ }^{* *}=T_{\min }{ }^{*}+T_{d} \operatorname{sign}\left(i_{\text {load }}\right)
\end{array}\right.
$$

$\langle\mathbf{4} \cdot \mathbf{3}\rangle$ 提案する転流方式により発生する電圧誤差 提 案する転流方式は，上記の電圧転流方式と電流転流方式を 組み合わせる。(4) 式，(7) 式を比較すると明らかなように， 2 つの転流方式で発生する誤差電圧の大きさは等しく，符 号のみが異なる。従って，提案する転流方式によって発生 する誤差は，負荷電流の極性と転流方式により，電圧転流 のとき $K_{\text {comm }}=1$, 電流転流のとき $K_{\text {comm }}=-1$ とすれば, 以下のように表せる。

$$
v_{\text {VIcomm }}=v^{*}-\left(v_{\max }-v_{\min }\right) T_{d} f_{s} \operatorname{sign}\left(i_{\text {load }}\right) K_{\text {comm }}
$$

よって，提案する転流方式は，電流極性と転流方式によっ て $T_{d}$ だけ誤差電圧が発生する。この誤差電圧を補償する には電流極性と転流方式を監視し，(10) 式のように $T_{\text {max }}{ }^{*}$ と $T_{\min }{ }^{*}$ のオン時間から $T_{d}$ を加減算することで，電圧転流 方式，電流転流方式と同様に補償できる。

$$
\left\{\begin{array}{l}
T_{\max }{ }^{* *}=T_{\max }{ }^{*}+T_{d} \operatorname{sign}\left(i_{\text {load }}\right) K_{\text {comm }} \\
T_{\min }{ }^{* *}=T_{\min }{ }^{*}-T_{d} \operatorname{sign}\left(i_{\text {load }}\right) K_{\text {comm }}
\end{array}\right.
$$

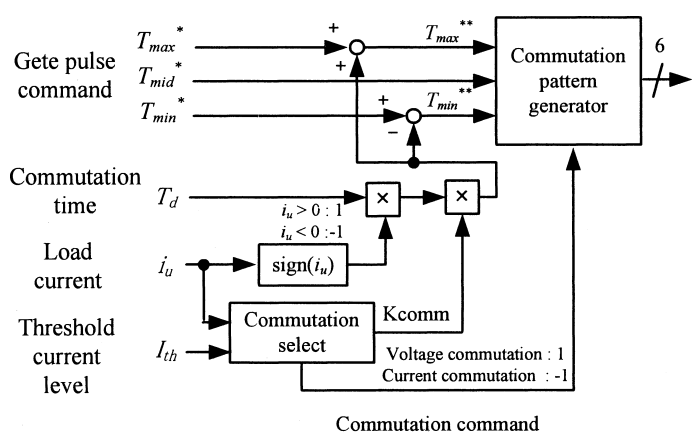

図 7 提案する転流誤差補償

Fig. 7. Proposed commutation error compensation.
図 7 に提案する転流誤差補償の 1 相分のブロック図を示 す。負荷電流（Load current）と電流しきい值（Threshold current level）より電圧転流方式と電流転流方式のどちらか を選択し転流パターンを付加する。その転流パターンと負 荷電流の極性により補償量を決定し, $T_{\max }{ }^{*}$ と $T_{\min }{ }^{*}$ に与え ることで，転流誤差を補償する。

\section{5. 実験結果}

提案する転流方式について, 実験により効果の検証を行っ た。表 1 に実験条件を示す。転流方式を切り替えるための 電流しきい值は，低すぎるとスイッチングリプル等による 検出ミスが発生し, 転流失敗する可能性があるため, ここで は定格電流のピーク值の約 20[\%] である 1.1 [A] とする。

図 8, 図 9 に電圧転流方式と電流転流方式の実験結果を示 す。図 8(a) は電圧転流方式の転流失敗の様子, 図 9(a) は電

表 1 実験条件

Table 1. Experimental parameter.

\begin{tabular}{|c|c|c|c|}
\hline Input voltage & $200[\mathrm{~V}]$ & \multirow{2}{*}{ LC filter } & $2[\mathrm{mH}]$ \\
\cline { 4 - 5 } Input frequency & $50[\mathrm{~Hz}]$ & $6.6[\mu \mathrm{F}]$ \\
\hline Cut-off frequency & $1.3[\mathrm{kHz}]$ & Commutation time & $2.5[\mu \mathrm{s}]$ \\
\hline R-L load & $\begin{array}{c}\mathrm{V} / \mathrm{f} \\
\text { control }\end{array}$ & $750[\mathrm{~W}]$ Motor & $\begin{array}{c}\text { Vector } \\
\text { control }\end{array}$ \\
\hline Output frequency & $20[\mathrm{~Hz}]$ & Motor speed & $600[\mathrm{rpm}]$ \\
\hline \multicolumn{3}{|c|}{ Threshold current level } & \multicolumn{2}{|c|}{ $\pm 1.1[\mathrm{~A}]$} \\
\hline
\end{tabular}

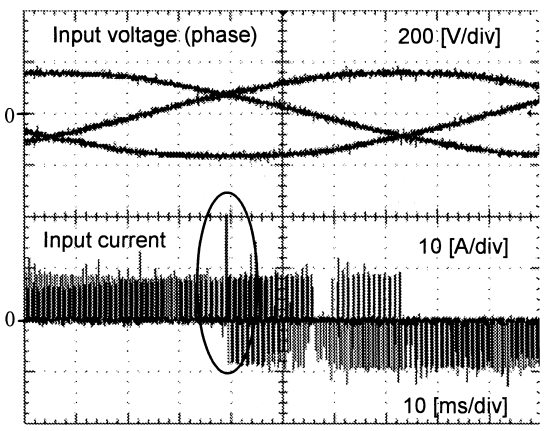

(a) Voltage commutation.

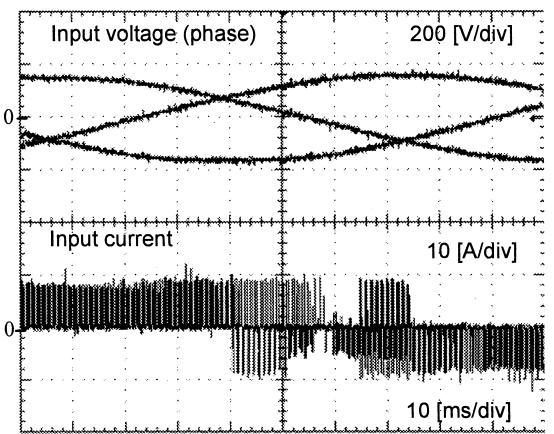

(b) Proposed commutation.

図 8 電圧転流と提案法の実験結果（R-L 負荷）

Fig. 8. Experimental result of voltage commutation and proposed commutation (R-L load). 
流転流方式の転流失敗の様子を示している。転流そのもの の違いを確認するため，負荷はR-L負荷としている。図 8, 図 9 に示す $\bigcirc$ 部で転流失敗が生じている。電圧転流方式 では，電源電圧の大小切り替わり付近において，電源電圧 の検出誤りにより電源短絡が発生し，入力電流にサージ電 流が発生している。一方，電流転流方式では，負荷電流ゼ ロクロス付近において，電流極性検出の誤りにより負荷開 放し，負荷電流のゼロクロス付近で出力電圧にサージ電圧 が発生している。さらに，電流転流方式では，極性検出を 誤ると転流出来なくなるため, 負荷電流がゼ口付近に停滞 し，波形がひずむことが確認できる。

図 8(b)，図 9(b) は提案する転流方式の波形である。提案 する転流方式では，電源電圧の大小切り替わり付近，負荷 電流のゼロクロス付近に扔いても，転流失敗をすること無 く，確実に転流しており，提案方式が効果的であることが 確認できる。

図 10 は入力電流と出力電流の 25 次までの T.H.D. の計 算結果である。入力電流について，電圧転流方式は，電源 電圧の大小切り替わり付近でのセンサの検出ミスによる転 流失敗などの影響により，入力電流にひずみが発生するた め，電流転流方式と比較すると T.H.D. が悪化する。

一方, 出力電流について, 電流転流方式では, 負荷電流 ゼロクロス付近におけるセンサの検出ミスによる転流失敗 や負荷電流検出信号の逆ヒステリシス特性のため, ゼロク ロス付近において波形がひずむ。そのため電圧転流方式と

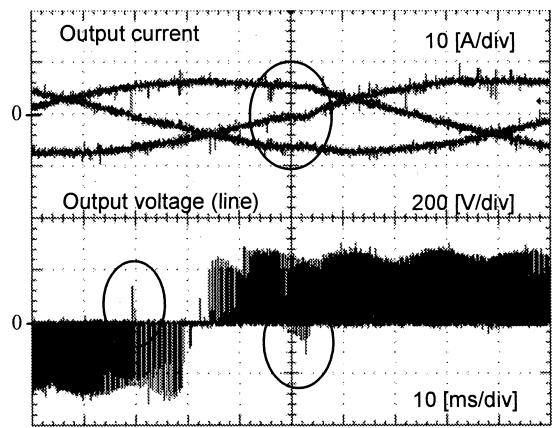

(a) Current commutation.

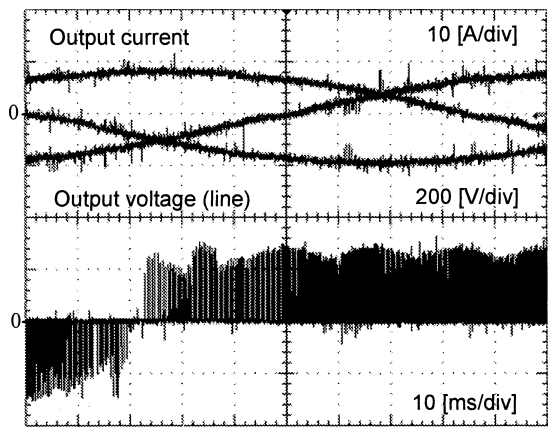

(b) Proposed commutation。

図 9 電流転流と提案法の実験結果 (R-L 負荷)

Fig. 9. Experimental result of current commutation and proposed commutation (R-L load).

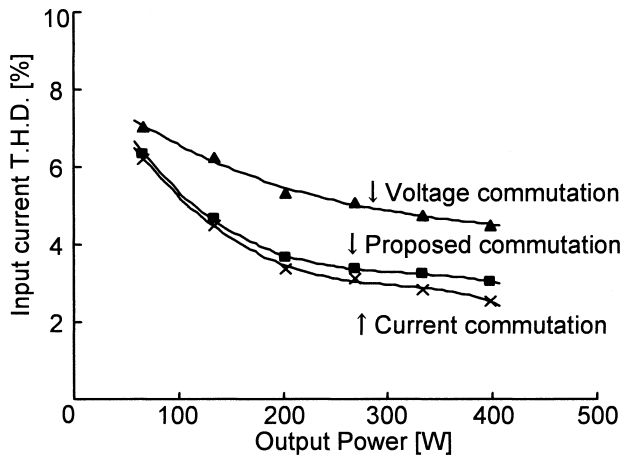

(a) T.H.D. of input current (R-L load).

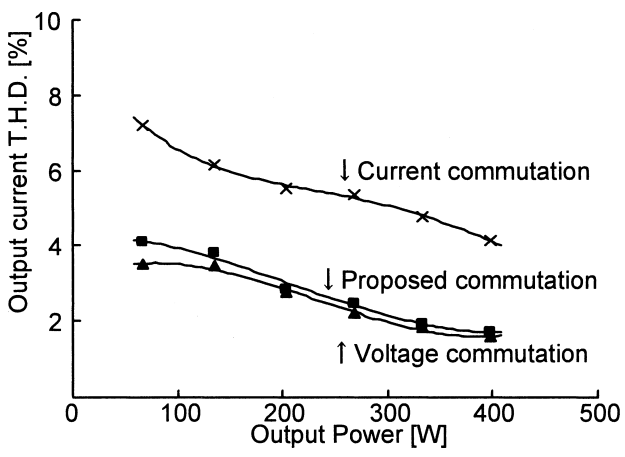

(b) T.H.D. of output current (R-L load).

図 10 入力電流と出力電流の T.H.D. (R-L 負荷)

Fig. 10. T.H.D. of input current and output current (R-L load).

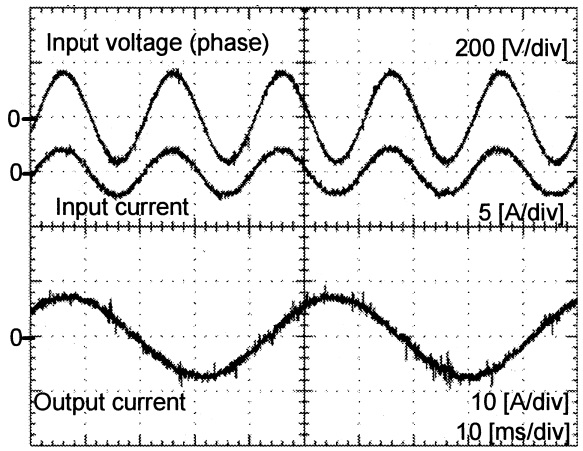

(a) Waveform of proposed method (Vector control).

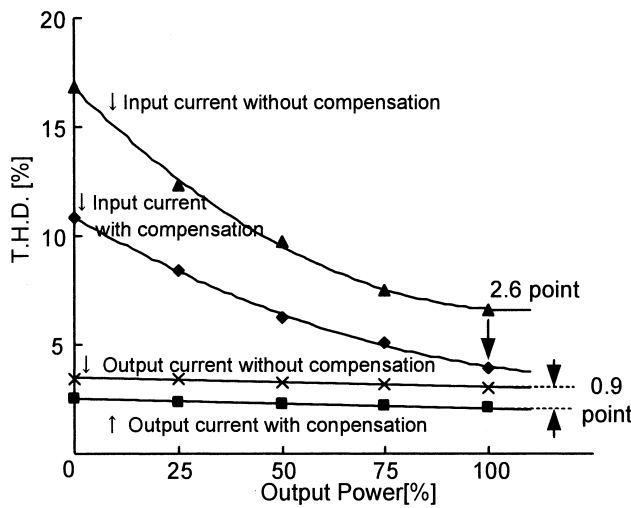

(b) T.H.D. of input current and output current (Vector control).

図 11 モー夕負荷の実験結果

Fig. 11. Experimental result of motor load. 
比較すると T.H.D. が悪化する。

提案する転流方式は,

-入力電圧の大小関係入れ替り付近... 電流転流方式

・負荷電流のゼロクロス付近…電圧転流方式

のように転流方式を組み合わせるため, 電源電圧の大小切 り替わり付近における入力電流ひずみと, 負荷電流ゼロク ロス付近における負荷電流ひずみの両方を低減できる。そ のため, 入力電流の T.H.D.について提案する転流方式と電 流転流方式, 出力電流 T.H.D. について提案する転流方式と 電圧転流方式，それぞれを比較すると大きな差がない。す なわち, 提案する転流方式は両方のトレードオフを解決し, 入出力ともに波形を改善できる。

図 11 は提案する転流方式にて，ベクトル制御によりモー 夕を駆動した場合の結果であり，入出力電流波形と 25 次ま での T.H.D. 結果を示している。提案する転流方式でモータ を制御しても良好な波形を得られることが確認できる。ま た，T.H.D. 結果において転流誤差補償有りと無しの場合を

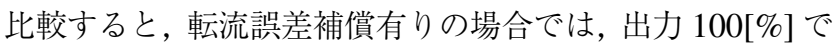
入力電流は 2.6 ポイント, 出力電流は 0.9 ポイント改善さ れており，提案する誤差補償方式が有効であることが確認 できる。また, 転流誤差補償を行った場合, 出力 100[\%]で 入力電流, 出力電流の T.H.D. はそれぞれ 3.9[\%], 2.1[\%] を達成している。

\section{6. まとめ}

本論文では，入力電圧の大小関係と負荷電流極性の両方 を用い，転流失敗の発生する回数を大幅に低減できる転流 方式を提案した。また，転流によって発生する誤差の関係 を明らかにし, 電圧転流と電流転流を切り替えた場合でも, 問題なく転流誤差を補償できる方法を提案した。R-L 負荷 と $750 \mathrm{~W}$ の誘導機により実験を行うことで従来方式と比較 し，その有効性を検証した。下記にその結論を示す。

（1）検出センサの精度を高めることなく，転流失敗を 低減できる。

（2）電源電圧切り替わり付近における入力電流ひずみ と, 出力電流ゼロクロス付近の負荷電流ひずみ両 方を低減できる。

（3）提案する転流方式の転流による電圧誤差は従来の 転流方式と同様に簡単に補償できる。

（4）ベクトル制御時の入力電流，出力電流の T.H.D.は 出力 $100[\%]$ でそれぞれ 3.9[\%]，2.1[\%] である。

以上のことから, 提案する転流方式は, 従来の転流方式 を組み合わせることで簡単に構成でき，転流失敗を低減す ることが出来る。これより，転流失敗で発生するサージを 吸収するスナバ容量を小さくでき，また素子の寿命の観点 から，提案する転流方式は非常に有効であると考える。

なお, 本研究の一部は平成 17 年度産業技術研究助成事業 の支援を受けており，関係各位に感謝の意を表します。

(平成 18 年 9 月 22 日受付, 平成 19 年 2 月 8 日再受付)

\section{文献}

(1) M. Takei, A. Odaka, and H. Fujimoto: "Application technique of Reverse blocking IGBT", Fuji review, Vol.75, No.8, 445-448 (2002) (in Japanese) 武井 学・ 小高章弘・藤本 久:「逆阻止 IGBT の適用技術」, 富士時 報, Vol.75, No.8, 445-448 (2002)

(2) J. Oyama, T. Higuchi, E. Yamada, T. Koga, and T. Lipo: "New Control Strategy for matrix converter", Proceedings of Power Electronics Society conference, pp.360-367 (1989)

(3) P.W. Wheeler, J. Rodriguez, J.C. Clare, and L. Empringham: "Matrix Converters: A Technology Review", IEEE Trans. I.E., Vol.49, No.2, pp.274-288 (2002)

(4) J. Itoh, I. Sato, H. Ohguchi, K. Sato, A. Odaka, and N. Eguchi: "A Control Method for the Matrix Converter Based on Virtual AC/DC/AC Conversion Using Carrier Comparison Method", IEEJ, Vol.124-D, No.5, 457-463 (2004-5) (in Japanese)

伊東淳一 - 佐藤以久也 · 大口英樹 - 佐藤和久 - 小高章弘 - 江口直也 : 「キャリア比較方式を用いた仮想 AC/DC/AC 変換方式によるマトリッ クスコンバータの制御法」, 電学論 D, 124, 5, 457-463 (2004-5)

(5) H. Hara, E. Yamamoto, M. Zenke, K. Kan, and T. Kume: "An Improvement of Output Voltage Control Performance for Low Voltage Region of Matrix Converter", Proc. of IEEJapan IAS 2002, pp.I-313-316 (1-48) (2004) (in Japanese)

原 英則·山本栄治·善家充彦·姜 俊求 · 久米常生：「低電圧領域 に拈けるマトリクスコンバータの電圧改善の一方策」, 平 16 産業応 用部門大会, 214 (2004)

(6) J. Oyama, X. Xia, T. Higuchi, K. Kuroki, E. Yamada, and T. Koga: "VVVF On-line Control of Matrix converter”, IEEJ, Vol.116-D, No.6, (2004) (in Japanese)

小山 純 · 夏 暁戎 ·樋口 剛 - 黒木恒二 - 山田英二 ·古賀高志： 「PWM サイクロンコンバータの VVVF オンライン制御」, 電学論 D, 116, 6, 644-651 (1996-6)

(7) J. Itoh, H. Tajima, and H. Ohsawa: "Induction Motor Drive System using V-connection AC Chopper", IEEJ, Vol.123-D, No.3 (2003-3) (in Japanese) 伊東淳一・田島宏一・大沢 博:「三相 V 結線交流チョッパを用い た誘導電動機駆動システム」, 電学論 D, 123, 3, 271-277 (2003-3)

(8) J. Mahlein, J. Igney, J. Weigold, M. Braun, and O. Simon: "Matrix Converter Commutation Strategies With and Without Explicit Input Voltage Sign Measurement", IEEE Trans. I.E., Vol.49, No.2, pp.407-414 (2002)

(9) P.W. Wheeler and D.A. Grant: "Optimized input filter design and low-loss switching techniques for a practical matrix converter", IEE Proceedings of Electric Power Applications, Vol.144, No.1, pp.53-60 (1997-1)

(10) K.G. Kerris, P.W. Wheeler, L. Empringham, and J.C. Clare: "Implementation of a Matrix Converter Using p-Channel MOS-Controlled Thyristors", IEE Conference on Power Electronics and Variable Speed Drives, London, (2000-9)

(11) L. Empringham, P.W. Wheeler, and J.C. Clare: "Intelligent Commutation of Matrix Converter Bi-directional Switch Cells using Novel Gate Drive Techniques", Proc. of IEEE Power Electronics Specialists Conference 1998 (PESC98), pp.707-713 (1998)

(12) M. Ziegler and W. Hofman: "Performance of a two step commutated matrix converter for ac-variable-speed drives", Proc. of EPE, No.258 (1999) (CD-ROM)

(13) P.W. Wheeler, J.C. Clare, and L. Empringham: "A MCT BASED MATRIX CONVERTER WITH MINIMIZED COMMUTATION TIMES AND ENHANCED WAVEFORM QUALITY", IEE Conference Publication (Institute of Electrical Engineers), Vol.487, pp.206-210 (2002)

(14) H. Ohguchi, J. Itoh, I. Sato, A. Odaka, H. kodachi, and N. Eguchi: "An Improvement Scheme of Control Performance for Matrix Converter" Proc. of EPE (2004)

(15) H. Hara, K. Kan, E. Yamamoto, K. Yamada, M. Zenke, and E. Watanabe: "Performance Improvement of Matrix Converter Drives", Proc. of IEEJapan IAS 2002, pp.931-934 (214) (2002) (in Japanese)

原 英則 ·姜 俊求 - 山本栄治 - 山田健二 · 善家充彦 ·渡辺英司 : 「マトリクスコンバータのドライブ性能改善」, 平 14 産業応用部門大 会, 214 (2002)

(16) M. Ziegler and W. Hofmann: "Semi natural two steps commutation strategy for matrix converters”, in Proc. IEEE PESC’98, pp.727-731 (1998)

(17) L. Wei, T.A. Lipo, and H. Chan: "Robust voltage commutation of the conventional matrix converter", Power Electronics Specialist Conference, 2003. PESC'03. 2003 IEEE 34th Annual Volume 2, 15-19 (2003-6) Page(s):717$722 \mathrm{Vol} .2$ 
加 藤 康 司 (学生員) 1983 年生。 2006 年 3 月長岡技術科学 大学卒業。同年 4 月同大学大学院工学研究科修士 課程電気電子情報工学専攻に進学。主に電力変換 回路に関する研究に従事。
伊 東 淳 - (正員) 1972 年生。1996 年 3 月長岡技術科学大

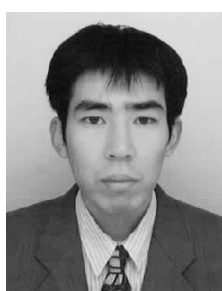
学大学院工学研究科修士課程修了。同年 4 月, 富 士電機 (株) 入社。2004 年 4 月長岡技術科学大学 電気系助教授。現在に至る。主に電力変換回路, 電動機制御の研究に従事。博士 (工学) (長岡技 術科学大学)。 